\title{
ANALISIS PELAT PERKERASAN KAKU RUAS JALAN SONGGORUNGGI- MALANGSARI KECAMATAN NGUTER SUKOHARJO DENGAN APLIKASI ATENA
}

\author{
Wibowo ${ }^{1)}$, Ary Setyawan ${ }^{2)}$, Handy Prasetyo ${ }^{3)}$ \\ 1),2)Pengajar Fakultas Teknik Jurusan Teknik Sipil Universitas Sebelas Maret Surakarta \\ 3)Mahasiswa Fakultas Teknik Jurusan Teknik Sipil Universitas Sebelas Maret Surakarta \\ Fakultas Teknik Jurusan Teknik Sipil Universitas Sebelas Maret Surakarta, \\ Jln Ir.Sutami 36A, Surakarta 57126. \\ Email : hpras@student.uns.ac.id
}

\begin{abstract}
Along with the development of science and technology in the field of civil engineering software, especially in the field of pavement structure analysis, therefore in planning and analyzing a rigid pavement, complex and specific methods are needed to obtain thick planning, use of reinforcement and internal forces due to the load accepted by rigid pavement, one of the real efforts made is the use of finite element-based ATENA software to determine the value of the internal forces, deflection and stress on the concrete slab. The purpose of this study is to be able to model pavement structures, analyze and compare the analysis results in the form of deflection, stress of concrete slabs on rigid pavement using the method and the westergaard solution ATENA application on the Songgorunggi-Malangsari road section of Nguter Sukobarjo District. From the analysis and calculations, with a variation of CBR 3\% to $6 \%$. The results obtained with the middle loading method without connection (1 plate), namely the maximum stress of $-0.04653 \mathrm{MPa}$ and the maximum deflection of $2.147 \mathrm{~mm}$ with the equation $y=-0.2749 x+2.398$ and $\mathrm{R}^{2}=0.9775$, with the middle loading method with the connection (4 plates), namely a maximum stress of -0.04161 MPa and a maximum deflection of 1.835 $m m$ which is expressed by the equation $y=-0.2281 x+2.0155$ and $\mathrm{R}^{2}=0.9647$, with the side loading method without joints (1 plate) namely the maximum stress of $-0.3057 \mathrm{MPa}$ and the maximum deflection of $3.893 \mathrm{~mm}$ with the equation $y=-0.6836 x+4.220$ and $\mathrm{R}^{2}=0.8391$, with the side loading method with joints (4 plates), namely the maximum stress of $-0.2333 \mathrm{MPa}$ and the maximum deflection is $2.804 \mathrm{~mm}$ which is expressed by the equation $y=-0.3672 x+2.900$ and $\mathrm{R}^{2}=0.7318$. So that by using reinforced concrete with a thickness of $25 \mathrm{~cm}$, wiremesh longitudinal and transversed 10-200 as well as dowel and joints tie bar are a viable alternative for the rehabilitation of the Songgorunggi-Malangsari Nguter Sukoharjo road, because the deflection and stress results are far from the safe limits of allowable deflection and allowable stress rigid pavement.
\end{abstract}

Keywords: Rigid pavement, deflection, stress, ATEN A software, wiremesh

\begin{abstract}
Abstrak
Seiring berkembangnya ilmu pengetahuan dan teknologi di bidang software teknik sipil, khususnya pada bidang analisis struktur perkerasan, oleh karena itu diperlukan metode yang kompleks dan spesifik sehingga diperoleh perencanaan tebal, penggunaan tulangan dan gaya-gaya dalam akibat beban yang diterima oleh perkerasan kaku, maka digunakan software ATENA yang berbasis elemen hingga, untuk mengetahui nilai besaran gaya-gaya dalam, lendutan dan dan tegangan pada pelat beton. Tujuan dari studi ini adalah mampu memodelkan struktur perkerasan, menganalisa dan membandingkan hasil analisis berupa lendutan, tegangan pelat beton pada perkerasan kaku menggunakan metode westergaard solution dan aplikasi ATENA pada ruas jalan Songgorunggi-Malangsari Kecamatan Nguter Sukoharjo. Dari hasil analisis dan perhitungan, dengan variasi CBR 3\% sampai 6\%. Didapatkan hasil dengan metode pembebanan tengah tanpa sambungan (1 pelat) yaitu tegangan maksimal sebesar $-0,04653 \mathrm{MPa}$ dan lendutan maksimal sebesar 2,147 $\mathrm{mm}$ dengan persamaan lendutan $\mathrm{y}=-$ $0,2749 x+2,398$ dan $R^{2}=0,9775$, dengan metode pembebanan tengah dengan sambungan (4 pelat) yaitu tegangan maksimal sebesar $-0,04161 \mathrm{MPa}$ dan lendutan maksimal sebesar 1,835 mm yang dinyatakan dengan persamaan lendutan $\mathrm{y}=-0,2281 \mathrm{x}$ $+2,0155$ dan $R^{2}=0,9647$, dengan metode pembebanan samping tanpa sambungan (1 pelat) yaitu tegangan maksimal sebesar -0,3057 MPa dan lendutan maksimal sebesar 3,893 mm dengan persamaan lendutan $y=-0,6836 x+4,220$ dan $R^{2}=$ 0,8391 , dengan metode pembebanan samping dengan sambungan (4 pelat) yaitu tegangan maksimal sebesar $-0,2333 \mathrm{MPa}$ dan lendutan maksimal sebesar 2,804 mm yang dinyatakan dengan persamaan lendutan y $=-0,3672 \mathrm{x}+2,900$ dan $\mathrm{R}^{2}=$ 0,7318. Sehingga dengan menggunakan beton bertulang tebal $25 \mathrm{~cm}$, wiremesh memanjang dan melintang $\mathrm{d} 10-200$ serta sambungan dowel dan tie bar adalah alternatif yang layak untuk desain ruas jalan Songgorunggi-Malangsari Nguter Sukoharjo, karena hasil lendutan dan tegangan jauh dari batas aman lendutan ijin dan tegangan ijin perkerasan kaku.
\end{abstract}

Kata Kunci: Perkerasan kaku, lendutan, tegangan, software ATEN A, wiremesh

\section{PENDAHULUAN}

Jalan merupakan salah satu prasarana penghubung darat yang berperan penting dalam kehidupan manusia. Salah satunya mendukung adanya perpindahan atau mobilisasi dari satu tempat ke tempat lainnya. Dalam pembangunannya, jalan memerlukan biaya yang banyak. Oleh karena itu, tahapan perencanaan suatu perkerasan jalan sangatlah penting. Perencanaan harus mempertimbangkan faktor ekonomi, lingkungan, sifat tanah dasar, beban lalu-lintas, fungsi jalan dan faktor-faktor lainnya. 
Perencanaan perkerasan jalan yang digunakan pun berkembang terus seiring berkembangnya ilmu pengetahuan dan teknologi. Diawali dengan perkerasan batu pecah dan batu belah. Saat ini penelitian tentang perencanaan perkerasan jalan maju sangat pesat seiring dengan bertambahnya jenis dan jumlah kendaraan. Sehingga mendesain jalan yang aman dan nyaman pun menjadi prioritas utama. Jenis perkerasan yang umum dipergunakan yaitu : perkerasan lentur/aspal (flexible pavement), perkerasan kaku/beton (rigid pavement), dan perkerasan komposit (composite pavement) (Shinta et.al., 2017).

Ruas jalan Songgorunggi - Malangsari di Kecamatan Nguter Kabupaten Sukoharjo merupakan Jalan Kabupaten yang menghubungkan PT. Rayon Utama Makmur dengan Jalan Wonogiri - Sukoharjo, pergerakan transportasi cukup padat.

Oleh karena itu dalam merencanakan suatu perkerasan kaku diperlukan metode yang kompleks dan spesifik sehingga diperoleh perencanaan tebal perkerasan beton. Maka perkuatan perkerasan kaku berupa tulangan dowel, tie bar ataupun wiremesh sangat dibutuhkan untuk mampu mendukung beban yang melintasi ruas jalan tersebut serta menambah umur rencana dari perkerasan kaku tersebut.

Dengan berkembangnya ilmu pengetahuan dan teknologi di bidang software, maka peneliti menggunakan aplikasi ATENA yang berbasis elemen hingga dengan tujuan untuk mengetahui nilai besaran gaya-gaya dalam, lendutan dan tegangan pada pelat beton yang nantinya akan dikomparasi hasilnya dengan analisis westergaard solution.

Dengan menggunakan aplikasi ATENA, diharapkan dapat mempermudah dan mempercepat dalam melakukan analisis terhadap pelat beton pada perkerasan kaku. Adanya aplikasi ATENA memungkinkan struktur pelat beton dapat dimodelkan menyerupai dengan struktur sesungguhnya pada lapangan dan mudah untuk mengetahui pola retak pada beton.

\section{METODE PENELITIAN}

Penelitian ini menggunakan metode deskriptif analitis, untuk mendeskripsikan atau memberi gambaran terhadap objek yang diteliti melalui data atau sampel yang telah terkumpul, dengan kata lain mengambil masalah atau memusatkan perhatian kepada masalah-masalah sebagaimana adanya saat penelitian dilaksanakan, hasil penelitian kemudian diolah dan dianalisis untuk diambil kesimpulannya. Data diperoleh dengan survei pengamatan jalan dan data sekunder yang ada dari pelaksana proyek berupa gambar as built drawing, data uji kuat tekan beton dan uji tarik baja. Analisis menggunakan persamaan westergaard dan program ATENA untuk memodelkan struktur, mendapatkan nilai lendutan dan tegangan pada pembebanan tengah dan samping dengan variasi CBR 3\% sampai $6 \%$. Model berupa Pelat $6 \times 3$ dengan ketebalan $25 \mathrm{~cm}$, tulangan wiremesh memanjang dan melintang, model dibagi menjadi pelat tanpa sambungan (1 pelat) dan pelat dengan sambungan dowel dan tie bar (4 pelat). Tahapan penelitian ini dengan melakukan pengumpulan data setelahnya melakukan analisis dengan membuat model geometri dan input properti material pada program ATENA 3D v.5.3.5 dengan dilakukan variasi CBR (spring), variasi pembebanan dan penggunaan tulangan sambungan. Keluaran berupa tegangan dan lendutan pelat perkerasan kaku pada setiap variasi.

\section{Perkerasan Kaku}

Perkerasan kaku adalah jenis perkerasan jalan yang menggunakan beton sebagai bahan utama perkerasan tersebut, perkerasan kaku merupakan salah satu jenis perkerasan jalan yang sering digunakan selain dari perkerasan lentur (Flexible Pavement). Perkerasan ini umumnya dipakai pada jalan yang memiliki kondisi lalu lintas cukup padat dan memiliki distribusi beban yang besar, seperti pada jalan lintas antar provinsi, jembatan layang, jalan tol, maupun pada persimpangan bersinyal (Tenriajen, 1999).

\section{ATENA}

ATENA merupakan program komputer berbasis elemen hingga khusus untuk menganalisis permasalahan struktur beton. Program ini dikeluarkan oleh Cervenka Consulting dalam bentuk full version dan demo version. Peneliti menggunakan ATENA versi 5.3.5.

\section{Tanah Dasar}

Tanah dasar adalah bagian dari perkerasan jalan yang berfungsi untuk menyalurkan beban lalu lintas dari lapisan perkerasan diatasnya. Pada konstruksi perkerasan kaku daya dukung tanah yang umum digunakan yaitu nilai CBR (California Bearing Ratio) dan nilai modulus rekasi tanah dasar (k). 


\section{Lapis Pondasi Bawah}

Merupakan lapisan antara plat beton dengan tanah dasar. Material yang sering digunakan pada lapisan subbase adalah unbound granular (sirtu) atau bound granular (CTSB, cement treated subbase). Fungsi dari lapisan subbase adalah sebagai lantai kerja pada perkerasan kaku.

\section{Tulangan Sambungan}

Tulangan sambungan terdiri dari tulangan sambungan arah melintang dan tulangan sambungan arah memanjang. Tulangan sambungan melintang adalah tulangan untuk mengakomodasi gerakan kembang susut ke arah memanjang pelat, disebut juga tulangan dowel. tulangan sambungan memanjang merupakan tulangan untuk mengakomodasi gerakan lenting akibat panas dingin pada siang dan malam hari, disebut juga tulangan tie bar.

\section{Lendutan}

Lendutan pada tanah dasar memberikan gambaran tentang perubahan bentuk dari suatu struktur perkerasan dalam keadaan elastis. Lendutan ijin merupakan batas kritis dari suatu perkerasan dimana apabila lendutan ijin sudah dilampaui maka struktur perkerasan tersebut dianggap gagal secara struktural dan tidak layak desain.

\section{HASIL DAN PEMBAHASAN}

Pemodelan Struktur (Denah)

Pemodelan struktur pelat beton model pelat tanpa sambungan dan dengan sambungan (4 pelat) dengan variasi pembebanan tengah dan samping dapat dilihat pada gambar 1 dan 2 .
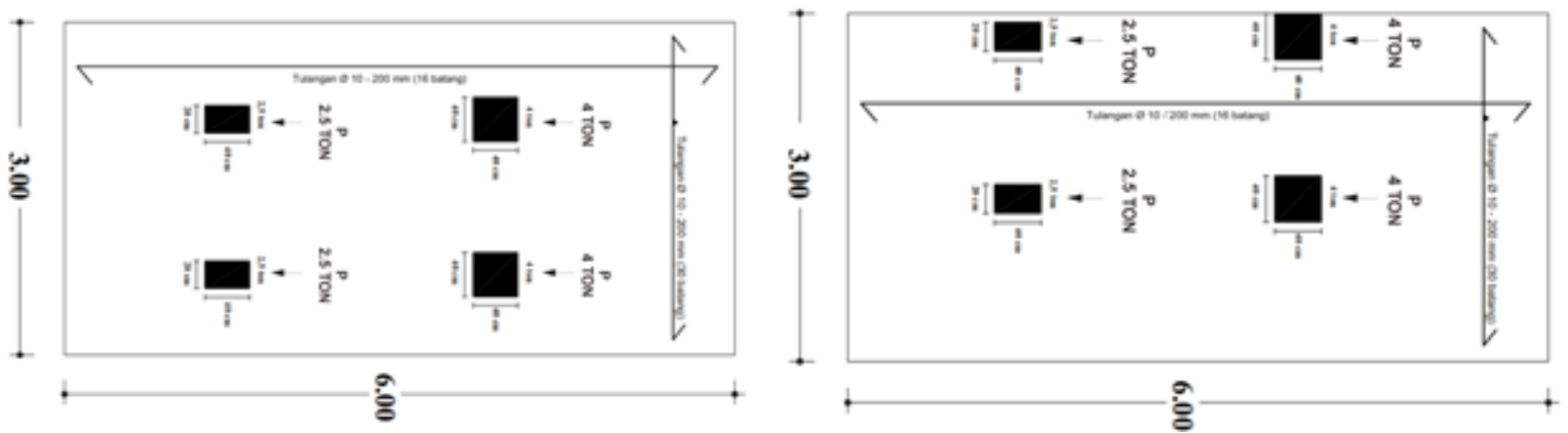

Gambar 1. Denah pembebanan tengah dan samping pelat tanpa sambungan

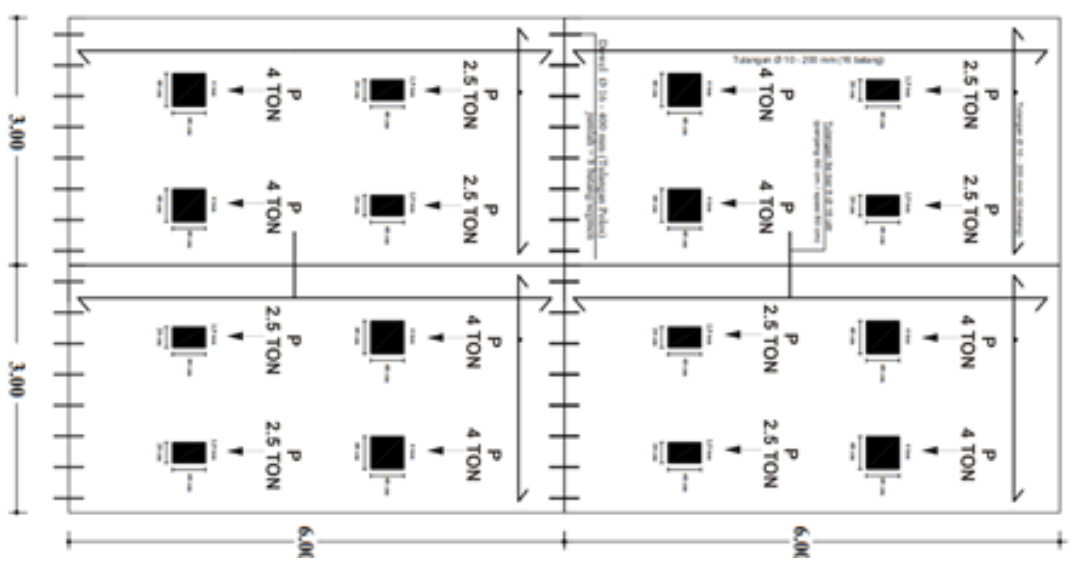




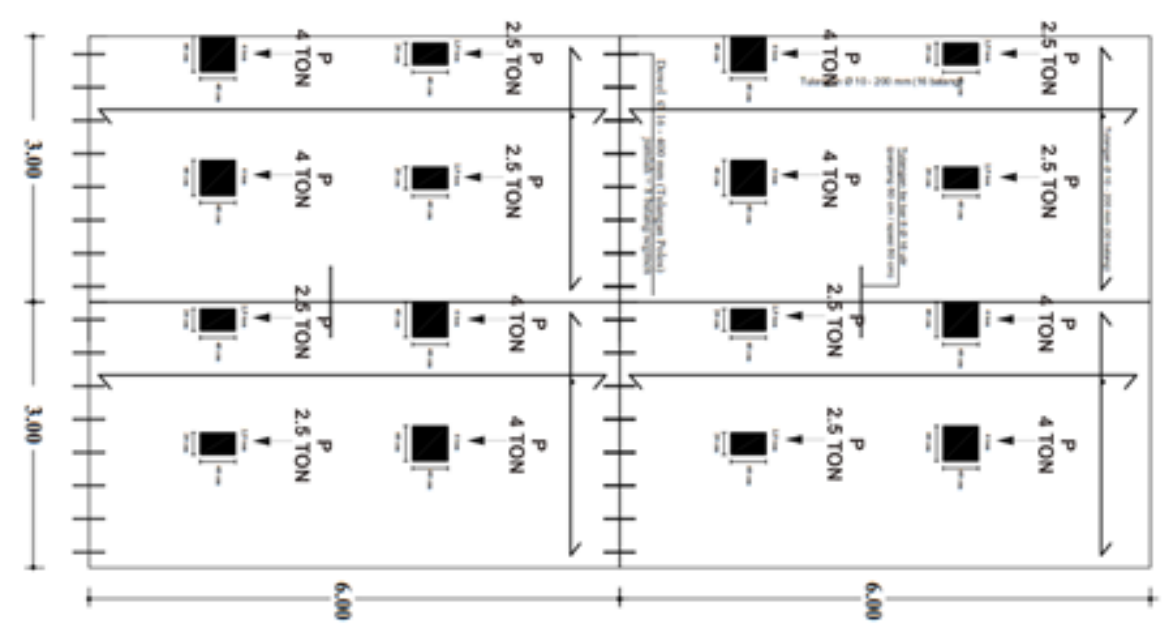

Gambar 2. Denah pembebanan tengah dan samping pelat dengan sambungan (4 Pelat)

\section{Pemodelan Struktur dengan Program ATENA}

Gambar penampang model dan pembebanan pada program ATENA disajikan dalam gambar 3 sampai 4.
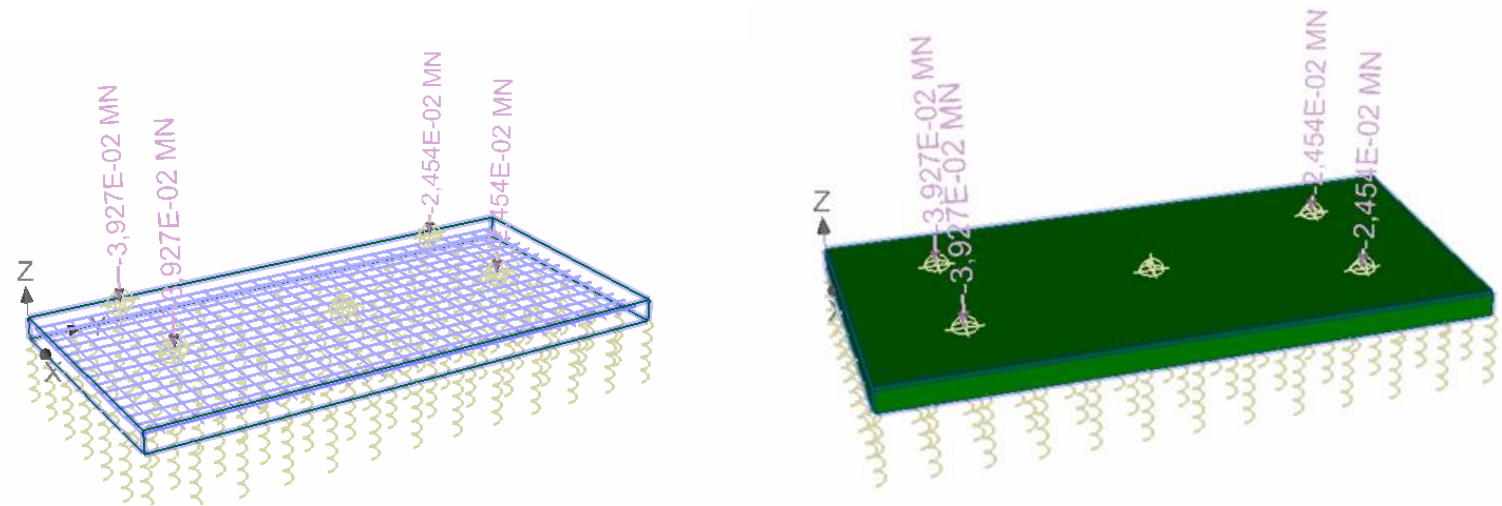

Gambar 3. Pembebanan tengah dan samping pelat tanpa sambungan pada program ATENA
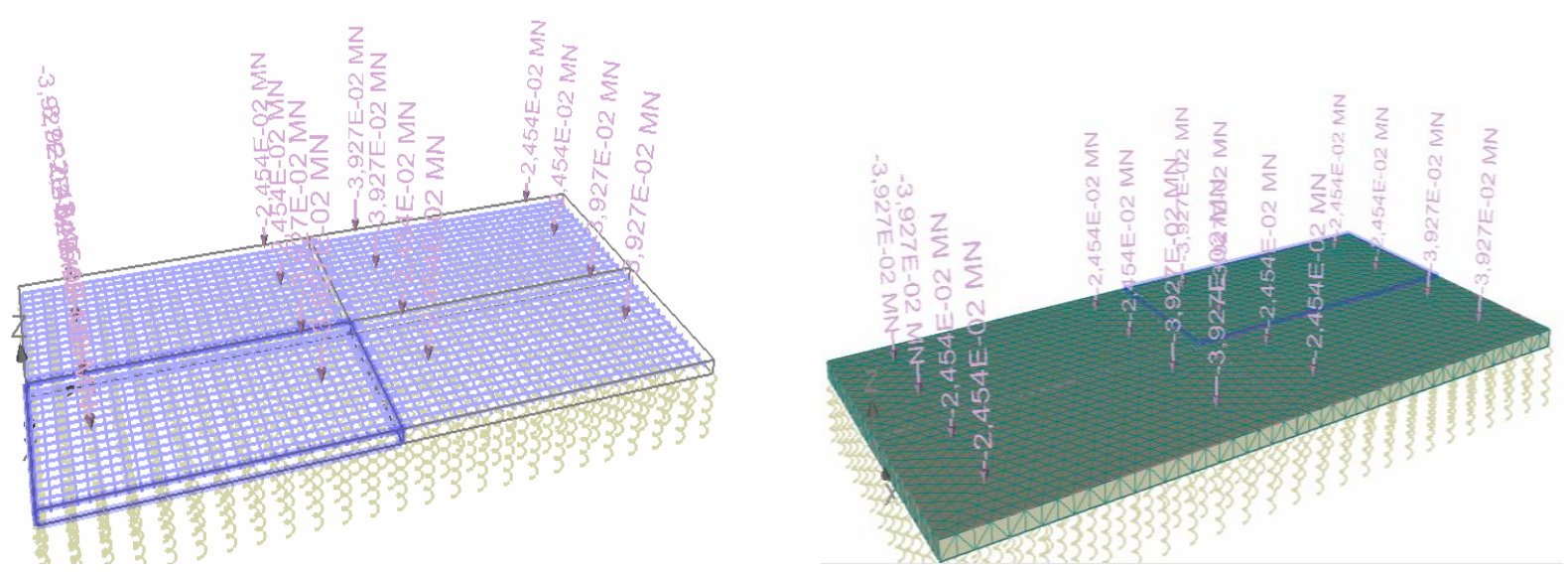

Gambar 4. Pembebanan tengah dan samping pelat dengan sambungan (4 pelat) pada program ATENA

Hasil yang didapatkan dalam analisis berupa tegangan dan lendutan yang ditampilkan dengan tabel dan grafik. Model berupa pelat $3 \times 6 \mathrm{~m}$, tebal $25 \mathrm{~cm}$, beban 8 ton dengan variasi CBR 3\% sampai 6\%, variasi pembebanan 
tengah dan samping dan variasi tanpa dan dengan sambungan. Spesifikasi material beton menggunakan mutu K300, tulangan wiremesh dengan spesifikasi BJ37 d10-200 searah memanjang dan melintang.

\section{Nilai Kekakuan Spring}

Tanah dasar yang dipakai sebagai tumpuan paling dasar perkerasan kaku yang diasumsikan sebagai tumpuan elastis yang memiliki kekakuan $(\mathrm{k})$ yang dimodelkan dalam aplikasi ATENA sebagai spring. Dalam analisis ini jarak antar tumpuan spring arah memanjang dan melintang sebesar $50 \mathrm{~cm}$. Nilai kekakuan spring dihitung berdasarkan model tumpuan pegas disajikan pada Tabel 1.

Tabel 1. Perhitungan kekakuan spring tanah dasar

\begin{tabular}{ccccc}
\hline $\begin{array}{c}\text { Variasi Nilai } \\
\text { CBR }\end{array}$ & $\mathrm{K}_{\mathrm{v}}\left(\mathrm{Kg} / \mathrm{cm}^{3}\right)$ & $\mathrm{k}_{1}(\mathrm{~kg} / \mathrm{cm})$ & $\mathrm{k}_{2}(\mathrm{~kg} / \mathrm{cm})$ & $\mathrm{k}_{3}(\mathrm{~kg} / \mathrm{cm})$ \\
\hline $3 \%$ & 2,7523 & 1720,188 & 3440,375 & 6880,750 \\
$4 \%$ & 3,3639 & 2102,438 & 4204,875 & 8409,750 \\
$5 \%$ & 3,7717 & 2357,288 & 4714,575 & 9429,150 \\
$6 \%$ & 4,2813 & 2675,813 & 5351,625 & 10703,25 \\
\hline
\end{tabular}

\section{Hasil Tegangan}

Tegangan menunjukkan kekuatan gaya yang menyebabkan perubahan pada pelat beton. Tegangan sangat dipengaruhi variasi pembebanan yang terjadi pada pelat beton. Berikut hasil tegangan pada program ATENA yang disajikan pada gambar 5 dan 6.
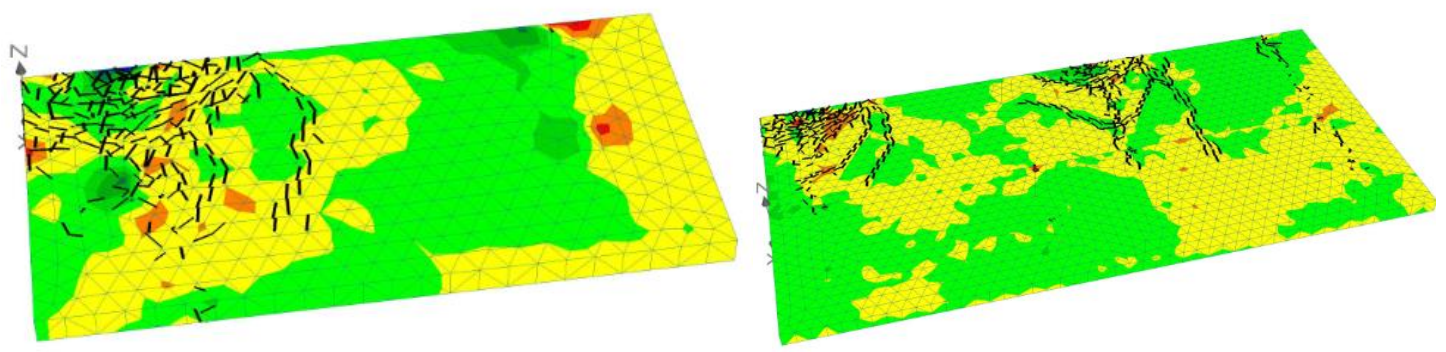

Gambar 5. Hasil tegangan pembebanan samping dengan ATENA 3D pada 1 pelat dan 4 pelat
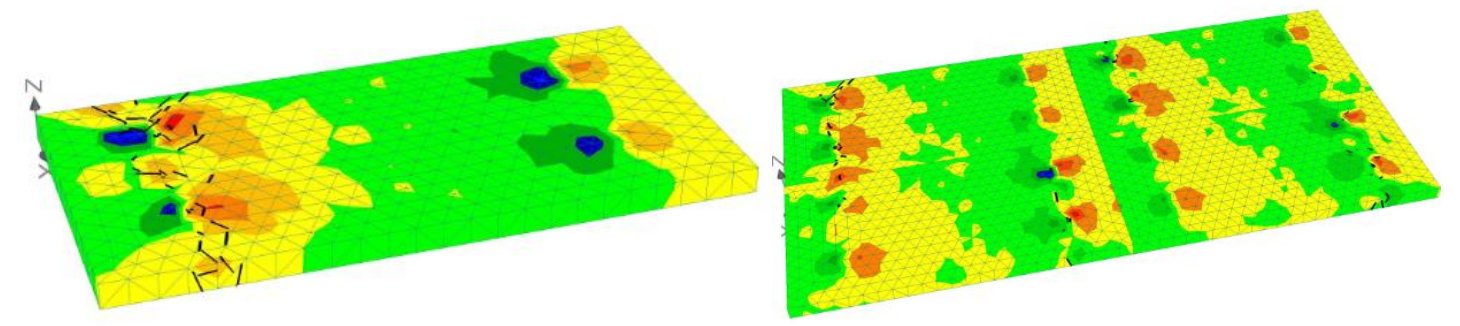

Gambar 6. Hasil tegangan pembebanan tengah dengan ATENA 3D pada 1 pelat dan 4 pelat

Tegangan maksimum terbesar terjadi pada variasi pembebanan samping didaerah roda belakang yang merupakan daerah yang mendapatkan beban tertinggi. Hasil analisis tegangan maksimum dapat dilihat pada tabel 2 dan 3 .

Tabel 2. Nilai tegangan maksimal pembebanan tengah dan samping tanpa sambungan

\begin{tabular}{ccccc}
\hline Nilai CBR & $\begin{array}{c}\text { Pembebanan Tengah } \\
(\mathrm{Mpa})\end{array}$ & $\begin{array}{c}\text { Pembebanan Samping } \\
(\mathrm{MPa})\end{array}$ & $\begin{array}{c}\text { Tegangan } \\
\text { Izin }\end{array}$ & Keterangan \\
\hline $3 \%$ & $-0,04437$ & $-0,1618$ & 3,45 & Aman \\
$4 \%$ & $-0,04553$ & $-0,1737$ & 3,45 & Aman \\
$5 \%$ & $-0,04593$ & $-0,2124$ & 3,45 & Aman \\
$6 \%$ & $-0,0463$ & $-0,3057$ & 3,45 & Aman \\
\hline
\end{tabular}


Tabel 3. Nilai tegangan maksimal pembebanan tengah dn samping dengan sambungan (4 pelat)

\begin{tabular}{ccccc}
\hline Nilai CBR & $\begin{array}{c}\text { Pembebanan Tengah } \\
(\mathrm{MPa})\end{array}$ & $\begin{array}{c}\text { Pembebanan Samping } \\
(\mathrm{MPa})\end{array}$ & $\begin{array}{c}\text { Tegangan } \\
\text { Izin }\end{array}$ & Keterangan \\
\hline $3 \%$ & $-0,04047$ & $-0,1650$ & 3,45 & Aman \\
$4 \%$ & $-0,04091$ & $-0,1809$ & 3,45 & Aman \\
$5 \%$ & $-0,04141$ & $-0,1883$ & 3,45 & Aman \\
$6 \%$ & $-0,04161$ & $-0,2333$ & 3,45 & Aman \\
\hline
\end{tabular}

Dapat disimpulkan bahwa tegangan yang terjadi pada struktur perkerasan tersebut belum melampaui batas yang diijinkan sehingga masih aman dengan Tegangan Izin Modulus Rupture $=0,62 \kappa \sqrt{f^{\prime} c}=3,45 \mathrm{MPa}$. Dengan demikian kedua jenis struktur perkerasan tersebut layak desain untuk diterapkan.

\section{Hasil Lendutan Pelat}

Lendutan ijin adalah batas kritis, struktur tidak layak dan aman jika melebihi batas lendutan ijin. Berikut hasil lendutan pada program ATENA yang disajikan pada gambar 7 dan 8 .
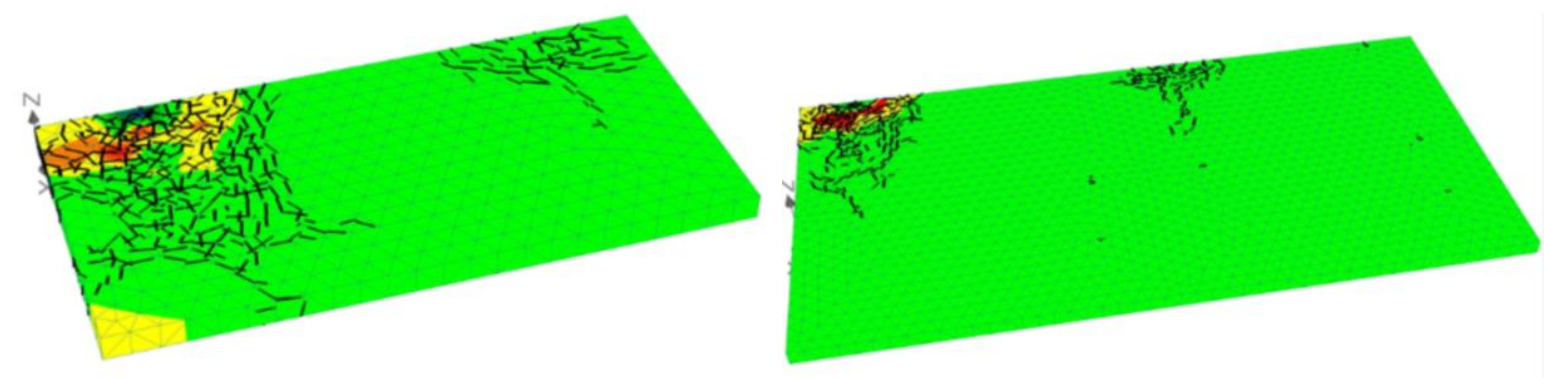

Gambar 7. Hasil lendutan pembebanan samping dengan ATENA 3D pada 1 pelat dan 4 pelat
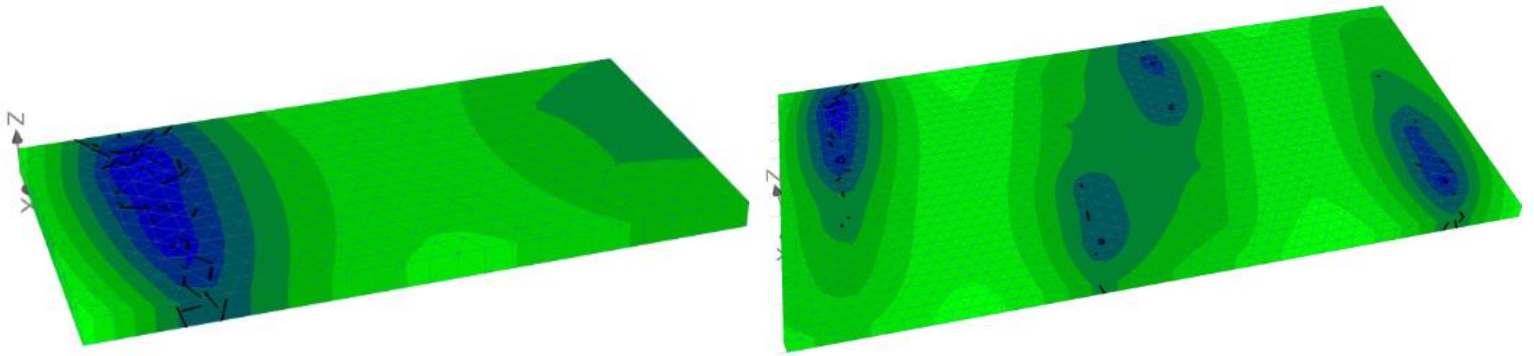

Gambar 8. Hasil lendutan pembebanan tengah dengan ATENA 3D pada 1 pelat dan 4 pelat

Tabel 4. Evaluasi lendutan pelat dengan persamaan westergaard dan program ATENA

\begin{tabular}{ccccccc}
\hline & \multicolumn{3}{c}{ Pembebanan Tengah } & \multicolumn{3}{c}{ Pembebanan Samping } \\
\cline { 2 - 7 } $\begin{array}{c}\text { CBR } \\
(\%)\end{array}$ & $\begin{array}{c}\text { Lendutan } \\
\text { ATENA } \\
\text { 1 Pelat }(\mathrm{mm})\end{array}$ & $\begin{array}{c}\text { Lendutan } \\
\text { ATENA } \\
\text { 4 Pelat } \\
(\mathrm{mm})\end{array}$ & $\begin{array}{c}\text { Lendutan } \\
\text { Westergaard } \\
(\mathrm{mm})\end{array}$ & $\begin{array}{c}\text { Lendutan } \\
\text { ATENA } \\
1 \text { Pelat } \\
(\mathrm{mm})\end{array}$ & $\begin{array}{c}\text { Lendutan } \\
\text { ATENA } \\
\text { 4 Pelat } \\
(\mathrm{mm})\end{array}$ & $\begin{array}{c}\text { Lendutan } \\
\text { Westergaard } \\
(\mathrm{mm})\end{array}$ \\
\hline 3 & 2,147 & 1,835 & 2,6302 & 3,893 & 2,804 & 1,0615 \\
4 & 1,850 & 1,514 & 2,3658 & 2,314 & 1,822 & 0,9563 \\
5 & 1,498 & 1,279 & 2,2268 & 2,177 & 1,672 & 0,9011 \\
6 & 1,348 & 1,153 & 2,0821 & 1,660 & 1,630 & 0,8424 \\
\hline
\end{tabular}




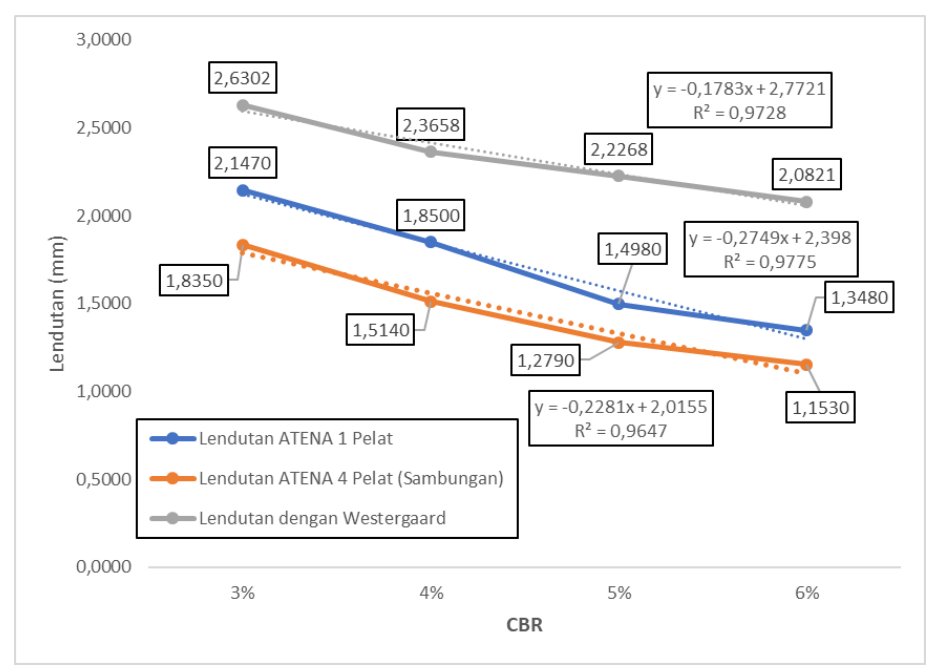

Gambar 9. Hubungan nilai CBR dengan lendutan pembebanan tengah

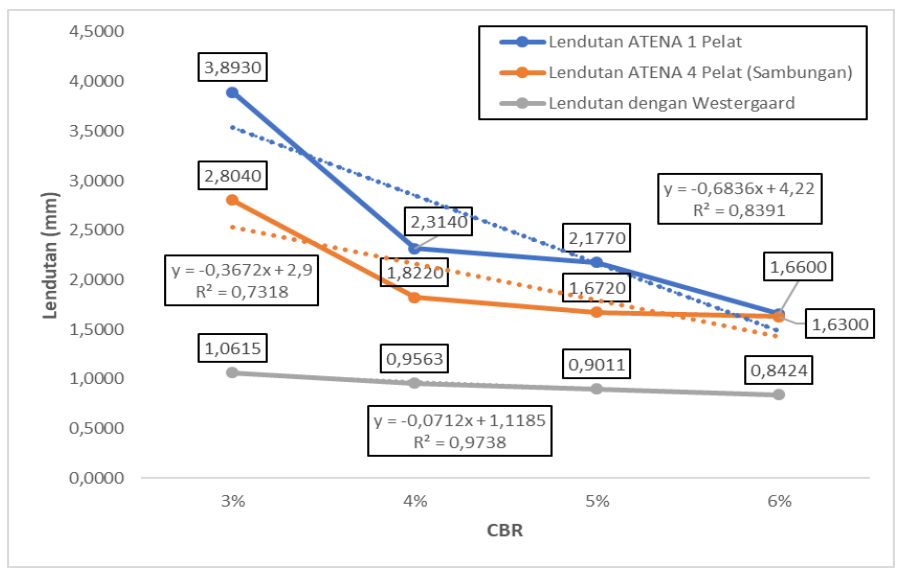

Gambar 10. Hubungan nilai CBR dengan lendutan pembebanan samping

\section{Pengaruh Nilai CBR}

Variasi CBR yang digunakan adalah 3\% sampai 6\%, Hasil dari analisis menunjukkan bahwa peningkatan nilai CBR pada tanah dasar dapat mengurangi lendutan pelat, karena semakin nilai kekakuan pada dasar tanah mampu menahan beban diatasnya sehingga lendutan menjadi tereduksi.

\section{Pengaruh Metode Pembebanan}

Letak pemberian beban memberikan pengaruh yang signifikan terhadap lendutan. Pembebanan samping memberikan hasil lendutan yang lebih besar dari pembebanan tengah yaitu sebesar 3,893 $\mathrm{mm}$. Persentase penurunan beban samping ke tengah sebesar 44,85\% yang artinya beban samping lebih signifikan berpengaruh pada hasil lendutan.

\section{Pengaruh Pemberian Sambungan Dowel dan Tie Bar}

Peneliti menggunakan tulangan dowel d16-400 mm, panjang $35 \mathrm{~cm}$, jumlah 8 batang per segmen dan tulangan tie bard16-400 mm, panjang $60 \mathrm{~cm}$, jumlah 8 batang per segmen. Hal itu memberikan pengaruh terhadap lendutan maksimal yang terjadi pada pembebanan samping yaitu sebesar $2,804 \mathrm{~mm}$ yang artinya mereduksi lendutan sebesar $27,97 \%$.

\section{KESIMPULAN}

Berdasarkan analisis data dan pembahasan yang telah dilakukan, dapat diambil kesimpulan sebagai berikut:

1. Berdasarkan hasil evaluasi analisis output Persamaan Westergaard dan ATENA 3D nilai lendutan dan tegangan maksimal mencapai $28,416 \%$ dan $8,861 \%$ dari lendutan dan tegangan izin sehingga dapat disimpulkan bahwa 
desain struktur perkerasan kaku dianggap layak sebagai desain perbaikan perkerasan pada kegiatan rehabilitasi dan pemeliharaan ruas jalan Songgorunggi-Malangsari Kecamatan Nguter, Sukoharjo.

2. Berdasarkan hasil analisis struktur desain perkerasan yang dilakukan dengan ATENA 3D didapatkan hasil besarnya tegangan dan lendutan maksimal yang terjadi pada dasar lapis perkerasan kaku dengan variasi pembebanan tengah dan pembebanan samping, yaitu :

a. Pembebanan Tengah tanpa Sambungan

Untuk nilai lendutan pada pembebanan tengah tanpa sambungan dapat dinyatakan dengan persamaan y = $-0,2749 \mathrm{x}+2,398$ dan $\mathrm{R}^{2}=0,9775$. Untuk nilai tegangan maksimal yaitu $-0,04653 \mathrm{MPa}$.

b. Pembebanan Tengah dengan Sambungan (4 Pelat)

Untuk nilai lendutan pada pembebanan tengah tanpa sambungan dapat dinyatakan dengan persamaan y $=$ $-0,2281 \mathrm{x}+2,0155$ dan $\mathrm{R}^{2}=0,9647$. Untuk nilai tegangan maksimal yaitu -0,04161 MPa.

c. Pembebanan Samping tanpa sambungan

Untuk nilai lendutan pada pembebanan samping dapat dinyatakan dengan persamaan $y=-0,6836 x+$ 4,220 dan $\mathrm{R}^{2}=0,8391$. Untuk nilai tegangan maksimal yaitu -0,3057 MPa.

d. Pembebanan Samping dengan Sambungan (4 Pelat)

Untuk nilai lendutan pada pembebanan samping dapat dinyatakan dengan persamaan $y=-0,3672 x+$ 2,900 dan $\mathrm{R}^{2}=0,7318$. Untuk nilai tegangan maksimal yaitu -0,2333 MPa.

3. Penggunaan sambungan dowel dan tie bar dapat mereduksi lendutan pada pembebanan tengah dan samping sampai $27,97 \%$ sehingga diperoleh perkerasan yang lebih aman dan layak dilewati kendaraan.

\section{REFERENSI}

Afriliyani, N., Puri, A., \& Ardiansyah, R., 2017, "Penerapan Modulus Reaksi Subgrade Ekivalen Lendutan Pelatpada Perkerasan"

Davids, W. G. (n.d.). "Experimental Verification of Rigid Pavement Joint Load Transfer Modeling with EverFE", Vol. 1 No. 99,pp. 81-89.

Jati, D. G., 2013, “Analisis Lentur Pelat Satu Aarah Beton Bertulang Berongga Bola Menggunakan Metode elemen Hingga Non Linier”, Vol. 7, pp. 24-26

Joaquim Barros, 1999, "Analysis of Concrete Slabs Supported on Soil"

Lunak, L., \& Puri, A., 2011, "Studi Eksperimental Lendutan Pelat yang Diperkuat Tiang-tiang Friksi Pendek pada Lempung Lunak", Februari.

Nugraha, W., Setiawan, B., \& Djarwanti, N., 2013, "Simulasi Perilaku Pelat Beton Sebagai Perkerasan Kaku di Atas Tanah Lunak Dengan Analisis Westergaard Solution”, pp. 296-303.

Puri, A., 2011, "Kontribusi Koperan dalam Mereduksi Lendutan Sistem Pelat Terpaku pada Lempung Lunak", December.

Saepudin, U. U., Sebelas, U., \& Surakarta, M., 2011, "Desain Bahan Perkuatan Perkerasan Kaku Dengan Over Slabbing ( Studi Kasus Ruas Jalan Cileunyi - Nagreg) Design Of Rigid Pavement Strengthening ( Case Study Road Cileunyi - Nagreg)" . Vol. 85.

Salles, L. S., \& Balbo, J. T., 2016, "Experimental Continuously Reinforced Concrete Pavement Parameterization Using Nondestructive Methods Parametrização De Pista Experimental De Pavimento”, Vol. 9 No. 2, pp.263-274.

Shinta NLP., 2017, "Pengaruh Nilai Cbr Tanah Dasar dan Mutu Beton Terhadap Tebal Pelat Perkerasan Kaku Metode Bina Marga"

Sulaiman, K. P., \& Wasono, S. B., 2019, "Perencanaan Perkerasan Kaku (Rigid Pavement) Dengan Menggunakan Wiremesh Pada Ruas Jalan HOS. Cokroaminoto dan Jalan Moch. Yamin (Tuban)", Ge-STRAM: Jurnal Perencanaan Dan Rekayasa Sipil, Vol. 2 No. 2, pp. 63. https://doi.org/10.25139/jprs.v2i2.1868

Tanah, R., Ekivalen, D., Struktur, U., \& Fleksibel, P., 2009, "Method Of Slab Deflection Using An Equivalent Modulus Of Subgrade Reaction For Flexible Slab Structures", Vol. 9, pp. 149-154.

Utomo Vian P., 2017, "Analisis Lendutan Perkerasan Kaku Pada Pembebanan Tengah Dan Tepi Dengan Metode Elemen Hingga"

Yasir, F., Surjandari, N. S., \& Purwana, Y. M., 2017, "Analisis Lendutan Perkerasan Kaku Pada Pembebanan Sudut Dengan Metode Elemen Hingga", Jumal Muara Sains, Teknologi, Kedokteran dan Ilmu Kesehatan

Y.H. Parjoko, 2012, "Sensitivity Analysis of Concrete Performance Using Finite Element Approach" 